\title{
PENGARUH PEMBELAJARAN QUANTUM BERBASIS KEARIFAN LOKAL TAT TWAM ASI TERHADAP KOMPETENSI PENGETAHUAN PKN SISWA KELAS IV SD GUGUS PB. SUDIRMAN DENPASAR BARAT
}

\author{
Gusti Ayu Made Indah Pradnyani,*, MG. Rini Kristiantari ${ }^{2}$, . I G.A. Agung Sri Asri ${ }^{3}$
}

${ }_{1}^{1}$ Jurusan Pendidikan Guru Sekolah Dasar Universitas Pendidikan Ganesha

2 Jurusan Pendidikan Guru Sekolah Dasar Universitas Pendidikan Ganesha

${ }^{3}$ Jurusan Pendidikan Guru Sekolah Dasar Universitas Pendidikan Ganesha

\begin{abstract}
Abstrak
Penelitian ini bertujuan untuk mengetahui perbedaan yang signifikan kompetensi pengetahuan PKn antara siswa kelas IV SD Gugus PB. Sudirman Denpasar Barat tahun ajaran 2016/2017 yang mengikuti pembelajaran Quantum berbasis kearifan lokal Tat Twam Asi dan yang mengikuti pembelajaran secara konvensional (pendekatan saintifik). Populasi penelitian adalah siswa kelas IV di Gugus PB. Sudirman Denpasar Barat. Sampel penelitian yaitu siswa kelas IVA SDN 6 Dauh Puri sebagai kelompok eksperimen dan siswa kelas IVB SDN 6 Dauh Puri sebagai kelompok kontrol. Data hasil kompetensi pengetahuan PKn siswa dikumpulkan dengan instrumen tes (pilihan ganda). Kemudian data dianalisis menggunakan analisis statistik deskriptif dan statistik inferensial uji-t. Berdasarkan hasil analisis data, diperoleh thitung $=2,30>t_{\text {tabel }}$ (pada taraf signifikansi 5\%) $=2,000$, dapat diinterprestasikan bahwa terdapat perbedaan yang signifikan kompetensi pengetahuan PKn antara kelompok siswa yang mengikuti pembelajaran quantum berbasis kearifan lokal tat twam asi dan kelompok siswa yang mengikuti pembelajaran secara konvensional. Dengan demikian dapat disimpulkan bahwa pembelajaran quantum berbasis kearifan lokal tat twam asiberpengaruh terhadap kompetensi pengetahuan siswa kelas IV SD Gugus PB. Sudirman Denpasar Barat Tahun Ajaran 2016/2017.
\end{abstract}

\section{PENDAHULUAN}

Pendidikan pada dasarnya adalah usaha sadar untuk menumbuhkan potensi sumber daya manusia peserta didik dengan cara mendorong dan memfasilitasi kegiatan belajar mereka. Pendidikan merupakan salah satu upaya untuk mengembangkan kemampuan individu dalam mengantisipasi kemungkinan-kemungkinan yang sedang dan akan terjadi (Trisnawati, 2015). Berdasarkan Undangundang Republik Indonesia Nomor 20 Tahun 2003 tentang Sistem Pendidikan Nasional Bab 1 Pasal 1, pendidikan didefinisikan sebagai usaha sadar dan terencana untuk mewujudkan suasana belajar dan proses belajar agar peserta didik secara aktif mengembangkan potensi dirinya untuk memiliki kekuatan spiritual keagamaan, pengendalian diri, kepribadian, kecerdasan, akhlak mulia, serta keterampilan yang diperlukan dirinya, masyarakat, bangsa dan negara. Pada dasarnya pendidikan laksana eksperimen yang tidak pernah selesai sampai kapan pun, sepanjang ada kehidupan manusia di dunia ini (Astuti, Ardana \& Manuaba, 2013).

Berdasarkan Undang-undang Sistem Pendidikan Nasional tujuan pendidikan dijelaskan sebagai pengembangan potensi peserta didik agar menjadi manusia yang beriman dan bertaqwa kepada Tuhan Yang Maha Esa, berakhlak mulia, sehat, berilmu, cakap, kreatif, mandiri, dan menjadi warga negara yang demokratis serta bertanggung jawab. Tujuan pendidikan nasional yang telah dipaparkan sejalan dengan visi pendidikan nasional yaitu terwujudnya sistem pendidikan sebagai pranata sosial yang kuat dan berwibawa untuk memberdayakan semua warga Indonesia berkembang menjadi manusia yang berkualitas sehingga mampu dan proaktif menjawab tantangan zaman yang selalu berubah-ubah.

\footnotetext{
* Corresponding author.

E-mail Addresses: indahpradnyani@yahoo.com (Gusti Ayu Made Indah Pradnyani), riniokanegara@gmail.com (MG. Rini Kristiantari)

xgungasrix@gmail.com (I G.A. Agung Sri Asri)
} 
Agar dapat mewujudkan tujuan pendidikan nasional maka disusunlah sebuah rencana tertulis yang dikenal dengan kurikulum. Kurikulum dalam Undang-undang Nomor 20 Tahun 2003 tentang Sistem Pendidikan Nasional dinyatakan sebagai seperangkat rencana dan pengaturan tujuan, isi, dan bahan pelajaran serta cara yang digunakan sebagai pedoman penyelenggaraan kegiatan pembelajaran untuk mencapai tujuan pendidikan tertentu. Penyempurnaan kurikulum terus dilakukan pemerintah agar kualitas pendidikan bisa lebih maju. Serentetan rangkaian penyempurnaan terhadap kurikulum diantaranya, pada tahun 2004 dirintis suatu kurikulum berbasis kompetensi, kemudian diteruskan dengan kurikulum 2006 (KTSP) dan sekarang telah diterapkan Kurikulum 2013.

Pada Permendikbud Nomor 57 Tahun 2014 Lampiran 1 dinyatakan kurikulum 2013 bertujuan untuk mempersiapkan manusia Indonesia agar memiliki kemampuan hidup sebagai pribadi dan warga negara yang beriman, produktif, kreatif, inovatif dan efektif serta mampu berkontribusi pada kehidupan bermasyarakat, berbangsa dan bernegara. Pada kurikulum 2013 siswa dituntut melalui beberapa proses secara aktif mencari, mengolah, mengkonstruksi, dan menerapkan pengetahuan. Kurikulum 2013 lebih menekankan pada kompetensi dengan pemikiran kompetensi berbasis sikap, keterampilan, dan pengetahuan melalui sebuah pendekatan yang dikenal dengan pendekatan saintifik (Daryanto, 2014).

Pendekatan Saintifik adalah proses pembelajaran yang dirancang sedemikian rupa agar siswa secara aktif mengkonstruk konsep, prinsip, melalui langkah-langkah pembelajaran yaitu mengamati, menanya, mengumpulkan informasi, mengasosiakan atau menalar, dan mengkomunikasikan. Pembelajaran yang menerapkan kurikulum 2013 dengan melaksanakan pembelajaran menggunakan pendekatan saintifik yang menurut Kunandar (2014) dikembangkan dengan rasional yang didasarkan pada faktor-faktor seperti: 1) tantangan internal antara lain terkait dengan kondisi pendidikan dikaitkan dengan tuntutan pendidikan yang mengacu kepada delapan Standar Nasional Pendidikan, 2) tantangan eksternal antara lain terkait dengan arus globalisasi dan berbagai isu yang terkait dengan masalah lingkungan hidup, kemajuan teknologi, dan informasi, kebangkitan industri kreatif dan budaya, dan perkembangan pendidikan di tingkat internasional, 3) penyempurnaan pola pikir, 4) penguatan tata kurikulum, dan 5) penguatan materi.

Pengembangan Kurikulum 2013 dengan menggunakan pendekatan saintifik ini dimaksudkan untuk memberikan pemahaman kepada peserta didik dalam mengenal, memahami berbagai materi menggunakan pendekatan ilmiah, bahwa informasi bisa berasal darimana saja, kapan saja, tidak bergantung pada informasi searah dari guru. Oleh karena itu, kondisi pembelajaran yang diharapakan tercipta diarahkan untuk mendorong peserta didik dalam mencari tahu dari berbagai sumber melalui observasi, dan bukan hanya diberi tahu. Pendekatan Saintifik yang telah diterapakan hingga saat ini, menjadi suatu kebiasaan dan keharusan dalam pelaksanaan pembelajaran di sekolah dasar. Oleh karena itu, pendekatan saintifik ini bisa dikatakan sebagai pembelajaran yang konvensional, artinya pembelajaran yang sudah biasa diterapkan dalam kurikulum 2013. Seiring berjalannya waktu perlu diadakannya suatu variasi pembelajaran guna menghindari kejenuhan dalam proses pembelajaran tersebut. Variasi pembelajaran tersebut dapat dideskripsikan sebagai pembelajaran yang menyenangkan, menumbuhkembangkan kemampuan untuk memecahkan masalah baru secara inovatif, sehingga siswa mampu memiliki pola pikir dan pola perilaku yang divergen, dan kemampuan kerja sama yang bersinergi dengan sesamanya. Pembelajaran yang memberikan kesempatan kepada siswa untuk belajar secara kreatif dan aktif dapat dilakukan dengan menggunakan pembelajaran yang sesuai dengan kondisi dan karakteristik siswa melalui pembelajaran Quantum berbasis kearifan lokal Tat Twam Asi. Implementasi pembelajaran tersebut diharapkan dapat memberi pengaruh terhadap kompetensi pengetahuan siswa, karena pembelajaran ini memberikan kesempatan kepada siswa untuk membangun pengetahuannya secara mandiri.

DePorter (2014) menyatakan Pembelajaran Quantum adalah pembelajaran yang mempunyai asas Bawalah Dunia Mereka ke Dunia Kita dan Antarkan Dunia Kita ke Dunia Mereka. Pembelajaran Quantum ini dapat membimbing peserta didik agar mau belajar dan menjadikan kegiatan yang dibutuhkan peserta didik, memotivasi, menginspirasi pembelajaran sehingga lebih menarik dan menyenangkan dan dapat menjadi lompatan kemampuan peserta didik setelah melakukan pembelajaran. Melalui pembelajaran kuantum siswa akan diajak belajar dalam suasana yang lebih nyaman dan menyenangkan, sehingga siswa akan lebih bebas menemukan berbagai pengalaman baru dalam belajarnya (Sukarsa dkk, 2014). Pendekatan Quantum Learning dikenalkan melalui konsep TANDUR (Tumbuhkan, Alami, Namai, Demonstrasikan, Ulangi, dan Rayakan) yang dapat membawa peserta didik menjadi lebih tertarik dan berminat untuk belajar (Buacani, 2016). Hal ini juga sejalan dengan hasil penelitiannya Kurniawati \& Syaichudin (2014) yang menyatakan bahwa implementasi model pembelajaran quantum learning secara signifikan dapat meningkatkan hasil belajar Bahasa Indonesia kompetensi dasar menulis karangan siswa kelas V SDN Lidah Wetan IV Surabaya. Pembelajaran Quantum dipadukan dengan kearifan lokal tat twam asi yang sarat dengan nilai etika. Pentingnya etika dalam pendidikan karena sesungguhnya etikalah yang 
merupakan hal utama dan pertama yang perlu ditindaklanjuti dalam pengelolaan pendidikan. Hal ini akan berdampak pada lebih bermutu dan lebih mantapnya pengelolaan suatu pendidikan. Pendidikan perlu diupayakan secara maksimal dalam mencapai tujuan serta target pencapaiannya. Maka dari itu pendidikan perlu menerapkan etika secara jelas dan konsisten. Bagaimanakah etika pendidikan bisa dipahami dan diterapkan dalam penyelenggaraan pendidikan? Menurut Subagiasta (2007) salah satu sumber ajaran mengenai etika pendidikan yang ada pada masyarakat di Bali yaitu kearifan lokal tat twam asi. Tat Twam Asi artinya, ia adalah kamu. Maksudnya adalah segala perilaku dan tindakan manusia diharapkan untuk tetap saling menghormati, menghargai, saling membantu dan saling menjunjung rasa senasib sepenanggungan, rasa kebersamaan dan adanya sikap toleransi terhadap semua komponen kehidupan di dunia ini.

Kearifan Lokal Tat Twam Asi ini identik dengan sila perikemanusiaan dalam Pancasila. Jika dicermati secara sungguh-sungguh, konsepsi sila perikemanusiaan dalam Pancasila merupakan realisasi dari Tat Twam Asi. Ia adalah kamu, saya adalah kamu, dan semua makhluk adalah sama. Tat Twam Asi juga dapat diartikan bahwa jiwaku adalah jiwamu dan jiwamu adalah jiwaku. Hal ini dapat dinyatakan sebagai ajaran kesamaan martabat manusia yang mempunyai arti bahwa semua manusia itu dilahirkan dengan derajat atau martabat yang sama. Karena itu manusia harus saling mencintai, saling menghargai. Dalam Pancasila, ajaran kesamaan martabat manusia dapat kita lihat dalam konsepsi Hak Asasi Manusia. Pada UU Nomor 39 Tahun 1999 tentang Hak Asasi Manusia dinyatakan bahwa Hak Asasi Manusia adalah seperangkat hak yang melekat pada hakikat keberadaan manusia sebagai makhluk Tuhan Yang Maha Esa. Hak Asasi Manusia dalam nilai dasar Pancasila tidak saja berisi kebebasan dasar, tetapi juga berisi kewajiban dasar yang melekat secara kodrati. Secara filsafati Pancasila memandang bahwa manusia dianugerahi oleh Tuhan Yang Maha Esa akal budi dan nurani yang memberi kemampuan untuk membedakan baik dan buruk, yang akan membimbing dan mengarahkan sikap dan perilaku manusia dalam menjalani kehidupan. Pancasila sebagai dasar negara mengandung konsep bahwa manusia diciptakan oleh Tuhan Yang Maha Esa bersifat monodualistik. Oleh sebab itu kebebasan setiap orang dibatasi oleh hak asasi orang lain. Ini berarti setiap orang mengemban kewajiban menjunjung tinggi hak asasi orang lain.

Berbicara tentang Pancasila dan Hak Asasi Manusia erat kaitannya dengan mata pelajaran Kewarganegaraan. "Pendidikan Kewarganegaraan adalah mata pelajaran yang digunakan sebagai wahana untuk mengembangkan dan melestarikan nilai luhur dan moral yang berakar pada budaya bangsa Indonesia" (Susanto, 2015:225). PKn merupakan salah satu mata pelajaran yang wajib dibelajarkan di Indonesia, disemua jenjang pendidikan mulai dari Sekolah Dasar hingga Perguruan Tinggi. Pada tingkat siswa sekolah dasar pendidikan Kewarganegaraan memberikan pelajaran pada siswa untuk memahami dan membiasakan dirinya dalam kehidupan di sekolah atau di luar sekolah, karena materi pendidikan Kewarganegaraan menekankan pada pengalaman dan pembiasaan pada kehidupan sehari-hari yang ditunjang oleh pengetahuan dan pengertian sederhana sebagai bekal untuk mengikuti pendidikan berikutnya.

Berdasarkan Permendiknas No. 22 Tahun 2006 tentang standar isi (dalam Aka, 2016), PKn merupakan salah satu mata pelajaran yang diajarkan pada tingkat sekolah dasar, pembelajaran PKn mengarahkan pada pembentukan warganegara yang memahami dan mampu melaksanakan hak-hak dan kewajibannya untuk menjadi warga negara Indonesia yang cerdas, terampil, dan berkarakter yang diamanatkan oleh Pancasila dan UUD 1945. Pembelajaran PKn di sekolah dasar dimaksudkan sebagai suatu proses belajar mengajar dalam rangka membantu peserta didik agar dapat belajar dengan baik dan membentuk manusia Indonesia seutuhnya dalam pembentukan karakter bangsa yang diharapkan mengarah pada penciptaan suatu masyarakat yang menempatkan demokrasi dalam kehidupan bernegara yang berlandaskan pada Pancasila, Undang-undang Dasar dan norma-norma yang diselenggarakan.

Pembelajaran Quantum yang dipadukan dengan kearifan lokal Tat Twam Asi adalah suatu pembelajaran yang memberikan pengalaman belajar bagi peserta didik dimana pembelajaran tersebut akan menumbuhkembangkan kemampuan peserta didik untuk memecahkan suatu masalah secara inovatif yang dilandaskan pada ajaran susila atau etika sehingga siswa dapat saling menghargai antar sesama dan menekan ego yang menjadi penghalang bagi kita untuk menyadari bahwa pada dasarnya diri kita semua adalah sama. Pada pembelajaran Quantum ini, gaya belajar siswa dibebaskan sesuai dengan karakteristik siswa tetapi tetap berpedoman pada Tat Twam Asi.

Berdasarkan pemaparan tersebut maka timbul suatu ketertarikan untuk melakukan penelitian mengenai pembelajaran Quantum berbasis kearifan lokal Tat Twam Asi yang diharapkan dapat mempermudah siswa dalam memahami mata pelajaran PKn. Ketertarikan untuk melakukan penelitian ini didukung oleh penelitian-penelitian serupa seperti: (1) penelitian Afa (2014) yang menyatakan terdapat perbedaan hasil belajar organ pernapasan manusia yang signifikan antara siswa yang mengikuti pembelajaran dengan strategi Quantum Teaching dengan dukungan MEDIA Audio Visual dengan 
kelompok siswa yang mengikuti pembelajaran konvensional; (2) penelitian Susiani (2013) yang menyatakan bahwa model pembelajaran Quantum berpengaruh positif terhadap prestasi IPA siswa; dan (3) penelitian Kusumawardani (2016) yang menyatakan bahwa penerapan Model Quantum Learning dengan menggunakan strategi TANDUR dapat meningkatkan motivasi belajar siswa pada mata pelajaran PKn.

Didasari pada beberapa fakta empiris bahwa pembelajaran Quantum dapat memberikan pengaruh dan juga dapat meningkatkan hasil belajar, maka peneliti tertarik untuk melakukan penelitian yang berjudul Pengaruh Pembelajaran Quantum Berbasis Kearifan Lokal Tat Twam Asi terhadap Kompetensi Pengetahuan PKn Siswa Kelas IV SD Gugus PB. Sudirman Denpasar Barat. Dari paparan tersebut, maka tujuan dari penelitian ini adalah untuk mengetahui perbedaan yang siginifikan kompetensi pengetahuan PKn antara kelompoksiswa kelas IV SDGugus PB. Sudirman Denpasar Barat yang dibelajarkan dengan Pembelajaran Quantum Berbasis Kearifan Lokal Tat Twam Asi dan kelompok siswa yang dibelajarkan dengan Pembelajaran Konvensional.

\section{METODE PENELITIAN}

Penelitian ini pada dasarnya bertujuan untuk mengetahui pengaruh pembelajaran quantum berbasis kearifan lokal tat twam asiterhadap kompetensi pengetahuan PKn siswa kelas IV SD Gugus PB. Sudirman Denpasar Barat pada semester genap tahun ajaran 2016/2017, dengan menggunakan jenis penelitian kuantitatif dengan desain eksperimental yaitu quasi eksperiment (Eksperimen Semu). Desain penelitian ini memiliki kelompok kontrol, namun tidak bisa berfungsi sepenuhnya untuk mengontrol variabel-variabel luar yang mempengaruhi pelaksanaan eksperimen (Sugiyono, 2012). Hal ini dikarenakan kemampuan peneliti dalam mengamati perilaku siswa sangat terbatas terutama ketika siswa berada di luar sekolah (rumah), peneliti juga tidak memiliki kemampuan untuk mengetahui persepsi siswa terhadap perlakuan secara pasti.

Bentuk desain eksperimen yang digunakan adalah Nonequivalent Control Group Design. Pada penelitian bentuk ini, biasanya digunakan pada kelas yang sudah terbentuk dan tidak melakukan pengacakan terhadap individu. Desain ini melibatkan 2 kelas yakni kelas yang mendapatkan perlakuan khusus dengan pembelajaran quantum berbasis kearifan lokal tat twam asi sebagai kelompok eksperimen, dan kelas yang menggunakan pembelajaran dengan pendekatan saintifik sebagai kelompok kontrol."Pemberian pra tes biasanya digunakan untuk mengukur equivalensi atau penyetaraan kelompok" (Dantes, 2012:97). Berdasarkan hal tersebut,maka dalam penelitian ini pra tes digunakan untuk menyetarakan kelompok. Teknik yang digunakan dalam penyetaraan adalah dengan menggunakan uji $t$.

Populasi dalam penelitian ini adalah seluruh siswa kelas IV SD di Gugus PB. Sudirman tahun ajaran 2016/2017 yang terdiri dari 6 sekolah. Jumlah keseluruhan populasinya adalah 479 orang.

Tabel 1. Komposisi Populasi Siswa

\begin{tabular}{|c|c|c|c|}
\hline No. & Sekolah & Kelas & Jumlah Siswa \\
\hline 1. & SDN 19 Dauh Puri & IV & 23 \\
\hline \multirow[t]{3}{*}{2.} & SDN 8 Dauh Puri & IVA & 43 \\
\hline & & IVB & 43 \\
\hline & & IVC & 42 \\
\hline 3. & SDN 5 Dauh Puri & IV & 42 \\
\hline \multirow[t]{2}{*}{4.} & SDN 6 Dauh Puri & IVA & 34 \\
\hline & & IVB & 33 \\
\hline \multirow[t]{2}{*}{5.} & SDN 24 Dau Puri & IVA & 40 \\
\hline & & IVB & 39 \\
\hline \multirow[t]{2}{*}{6.} & SD Muhamadyah II & IV & 140 \\
\hline & Jumlah & & 479 \\
\hline
\end{tabular}

Pemilihan sampel yang digunakan untuk memilih kelas sebagai kelompok eksperimen dan juga sebagai kelompok kontrol adalah dengan teknik Random Sampling. Pada teknik ini yang dirandom atau diacak adalah kelasnya, sehingga setiap kelas mendapatkan peluang yang sama untuk menjadi sampel penelitian.Pemilihan sampel penelitian ini tidak dilakukannya pengacakan individu melainkan hanya pengacakan kelas. Karena tidak bisa mengubah kelas yang telah terbentuk sebelumnya. Kelas dipilih sebagaimana telah terbentuk tanpa campur tangan peneliti dan tidak dilakukannya pengacakan individu, kemungkinan pengaruh-pengaruh dari keadaan siswa mengetahui dirinya dilibatkan dalam eksperimen dapat dikurangi sehingga penelitian ini benar-benar menggambarkan pengaruh perlakuan yang diberikan. 
Pengambilan sampel secara random dapat dilakukan dengan undian (Sugiyono, 2016). Setiap kelas yang ada dalam populasi diberi nomor urut terlebih dahulu, kemudian dilakukan random dan diambil 2 kelas sebagai sampel. Sampel yang diperoleh dari hasil random adalah kelas IVA SDN 6 Dauh Puri yang berjumlah 34 orang siswa dan kelas IVB SDN 6 Dauh Puri yang berjumlah 33 orang siswa. Sampel penelitian tersebut selanjutnya diberikan pre testuntuk penyetaraan. Data hasil pre test dianalisis menggunakan uji-t. Sebelum dilakukan uji-t, data hasil pre test diuji prasyarat yaitu dengan uji normalitas dan uji homogenitas. Pada uji normalitas dan homogenitas hasil data pre test diketahui bahwa data yang diperoleh dari kedua sampel berdistribusi normal dan memiliki varian yang homogen. Selanjutnya data hasil pre test diuji kesetaraan menggunakan uji-t. setelah mengetahui kedua sampel setara, peneliti melakukan pengundian pada kedua sampel untuk mencari kelas eksperimen dan kelas kontrol. Setelah diundi, untuk mencari kelas eksperimen dan kelas kontrol, undian yang muncul adalah SDN6 Dauh Puri kelas IVA dengan jumlah 34 orang siswa sebagai kelas eksperimen yang diberikan perlakuan berupa Pembelajaran Quantum Berbasis Kearifan Lokal Tat Twam Asi dan SDN6 Dauh Puri kelas IVB dengan jumlah 33 orang siswa sebagai kelas kontrolyang melaksanakan pembelajaran dengan pembelajaran konvensional yaitu pembelajaran dengan pendekatan saintifik.

Metode pengumpulan data yang digunakan dalam penelitian ini adalah metode tes. Metode tes adalah metode penelitian psikologis untuk mendapatkan informasi tentang berbagai aspek dalam tingkah laku dan kehidupan batin seseorang, dengan menggunakan pengukuran yang menghasilkan suatu deskripsi kuantitatif tentang aspek yang diteliti. Keunggulan dari metode tes ini adalah lebih akurat karena tes berulang-ulang direvisi dan instrumen penelitian yang objektif. Data yang akan dianalisis adalah data kompetensi pengetahuan PKn siswa. Untuk mendapatkan data kompetensi pengetahuan PKn digunakan tes kompetensi pengetahuan PKn. Tes yang akan digunakan untuk mengukur kompetensi pengetahuan PKn berupa tes objektif dalam bentuk pilihan ganda biasa. Tes ini terdiri dari 30 butir soal yang meliputi 4 pilihan jawaban (a, b, c atau d). Setiap item diberikan skor 1 bila siswa menjawab dengan benar (jawaban disesuaikan dengan kunci jawaban) dan skor 0 bila siswa menjawab salah.Skor setiap jawaban benar dibagi skor maksimal ideal dikalikan 100 dan hasil tersebut menjadi skor variabel kompetensi pengetahuan PKn yang bergerak dari kisaran 0-100. Tes yang baik adalah tes yang memenuhi dua syarat yaitu ketepatan (validitas) dan keajegan (reliabelitas). Tes yang digunakan untuk mendapatkan data kompetensi pengetahuan PKn sebelumnya telah dilakukan pengujian kelayakan instrumen yang meliputi uji validitas, uji reliabelitas, uji daya beda dan uji indeks kesukaran.

Teknik yang digunakan untuk menganalisis data guna menguji hipotesis penelitian adalah uji-t (polled varians). Polled Varians digunakan karena jumlah sampel kelompok eksperimen dan kelompok kontrol berbeda. Sebelum melakukan uji hipotesis, ada beberapa persyaratan yang harus dipenuhi dan perlu dibuktikan. Persyaratan yang dimaksud yaitu data yang akan dianalisis harus berdistribusi normal dan homogen.

\section{HASIL DAN PEMBAHASAN}

Deskripsi data kompetensi pengetahuan PKn kelompok eksperimen dan kelompok kontrol dapat dilihat padatabel 2 berikut ini

Tabel 2. Deksripsi Data Kompetensi Pengetahuan PKn

\begin{tabular}{ccc}
\hline Statistik & Kelompok Eksperimen & Kelompok Kontrol \\
\hline Mean & 66,79 & 60,64 \\
Standar Deviasi & 11,17 & 10,64 \\
Varians & 124,67 & 113,13 \\
Skor Maksimum & 93 & 90 \\
Skor Minimum & 50 & 43 \\
\hline
\end{tabular}

Berdasarkan tabel 2, rerata nilai kompetensi pengetahuan PKn siswa kelompok eksperimen lebih dari rerata kelompok kontrol. Hasil post-test terhadap 34 orang siswa kelas IVB SDN 6 Dauh Puri yang melaksanakan pembelajaran dengan pembelajaranQuantum berbasis kearifan lokal Tat wam Asi dalam kelompok eksperimen menunjukkan bahwa skor tertinggi yang diperoleh siswa adalah 93 dan skor terendah adalah 53, dengan rata-rata 66.79. Berdasarkan analisis nilai kompetensi pengetahuan PKn siswa pada kelompok eksperimen, kemudian dibandingkan dengan nilai KKM muatan pembelajaranPKn adalah 75 Dapat diketahui bahwa 26,47\% siswa pada kelompok eksperimen mendapatkan nilai diatas KKM dan 73,53\% mendapat nilai dibawah KKM. Jika rata-rata hasil analisis nilai kompetensi pengetahuan PKn dibandingakan ke dalam PAP skala 5, maka memperoleh hasil predikat Cukup Baik. 
Hasil ini berbeda dengan perolehan post-test kelompok kontrol. Hasil post-test terhadap 33 orang siswa kelas IVB SDN 6 Dauh Puri yang melaksanakan pembelajaran dengan pembelajaran konvensional dalam kelompok kontrol, menunjukkan bahwa skor tertinggi yang diperoleh siswa adalah 90 dan skor terendah adalah 43, dengan rata-rata 60,64. Berdasarkan analisis nilai kompetensi pengetahuan PKN siswa pada kelompok kontrol, kemudian dibandingkan dengan nilai KKM muatan pembelajaran PKN adalah 75. Dapat diketahui bahwa 9,09\% dari jumlah siswa siswa pada kelompok kontrol mendapatkan nilai diatas KKM dan 90,91\% dari jumlah siswa pada kelompok kontrol mendapat nilai dibawah KKM. Jika rata-rata hasil analisis nilai kompetensi pengetahuan PKn dibandingakan ke dalam PAP skala 5, maka memperoleh hasil predikat Kurang Baik.

Sebelum melakukan uji hipotesis, harus dilakukan beberapa uji prasyarat, yaitu uji normalitas sebaran data dan uji homogenitas varians. Uji normalitas sebaran data dilakukan untuk membuktikan bahwa kedua data sampel penelitian berdistribusi normal. Rekapitulasi hasil analisis uji normalitas kompetensi pengetahuan PKn kelompok eksperimen dan kelompok kontrol disajikan pada Tabel 3 berikut ini.

Tabel 3. Hasil Uji Normalitas Kelompok Eksperimen dan Kelompok Kontrol

\begin{tabular}{ccccc}
\hline No. & Sampel & $\mathrm{X}^{2}$ hitung & $\mathrm{X}^{2}$ tabel & Keterangan \\
\hline 1 & Kelompok Eksperimen & 5.59 & 11.07 & Normal \\
2 & Kelompok Kontrol & 5.52 & 11.07 & Normal \\
\hline
\end{tabular}

Berdasarkan tabel 2 dapat dilihat hasiluji normalitas menunjukkan bahwa data berdistribusi normal. Uji normalitas data dilakukan dengan menggunakan analisis Chi-Square dengan rumus $X^{2}{ }_{h i t}=\sum_{i}^{n} \frac{\left(f_{0}-f_{e}\right)^{2}}{f e}$ dan ketentuan harga $\left(\mathrm{X}^{2}\right.$ hitung $)$ yang diperoleh dibandingkan dengan harga $\left(\mathrm{X}^{2}\right.$ tabel $)$ dengan derajat kebebasan $(\mathrm{db})=($ jumlah klasifikasi-1) $=(6-1)=5$ dan taraf signifikansi $5 \%=11,07$. Berdasarkan hasil uji normalitas kelompok eksperimen pada lampiran 25, harga $\chi_{\text {hit }}^{2}$ yang diperoleh dari kelompok eksperimen $\chi_{\text {hit }}^{2}=\sum_{1}^{6} \frac{(f o-f e)^{2}}{f e}=5,59$. Harga tersebut kemudian dibandingkan dengan harga $X^{2}$ tabel dengan $\mathrm{db}=5$ dan taraf signifikansi $5 \%$ sehingga diperoleh harga $X_{\text {tabel }}^{2}=11,07$. Tabel nilai-nilai $c h i-$ square dapat dilihat pada lampiran. Karena $X^{2}{ }_{h i t u n g}<X^{2}$ tabel $(5,59<11,07)$ maka $H_{0}$ diterima (gagal ditolak) atau $\mathrm{H}_{\mathrm{a}}$ ditolak. Ini berarti sebaran data kompetensi pengetahuan PKN kelompok eksperimen berdistribusi normal.

Sedangkan pada kelompok kontrol, hasil uji normalitas kelompok kontrol pada lampiran 26.Harga $\chi_{\text {hit }}^{2}$ yang diperoleh dari kelompok kontrol adalah $\chi_{\text {hit }}^{2}=\sum_{1}^{6} \frac{(f o-f e)^{2}}{f e}=5,52 \mathrm{Harga}$ tersebut kemudian dibandingkan dengan harga $X^{2}$ tabel dengan $\mathrm{db}=5$ dan taraf signifikansi 5\% sehingga diperoleh harga $X_{\text {tabel }}=11,07$ karena $X^{2}$ hitung $<X^{2}$ tabel $(5,52<11,07)$ maka $\mathrm{H}_{\mathrm{o}}$ diterima atau $\mathrm{H}_{\mathrm{a}}$ ditolak. Ini berarti sebaran data kompetensi pengetahuan PKN kelompok kontrol berdistribusi normal.

Setelah melakukan uji normalitas sebaran data, selanjutnya dilakukan uji homogemitas varians terhadap kompetensi pengetahuan PKn siswa. Uji homogenitas varians dilakukan terhadap kompetensi pengetahuan PKn antara kelompok eksperimen dan kelompok kontrol.pengujian hipotesis varians menggunakan uji F pada taraf signifikansi $5 \%(\alpha=0,05)$ dan F hitung $=1,10$. Hasil uji homogenitas varians untuk taraf signifikansi $5 \% \mathrm{Ft}_{\text {abel }}$ dengan $\mathrm{db}(33,32)$ adalah 1,82. Ini menunjukkan hasil Fhit<Ftabel $(1.10<1.82)$ sehingga data homogen.

Berdasarkan pemaparan tersebut, dapat diketahui bahwa hasil uji prasyarat yaitu uji normalitas sebaran data dan uji homogenitas varians menunjukkan bahwa data dari kelompok eksperimen dan kelompok kontrol berdistribusi normal dan homogen. Karena data berdistribusi normal dan homogen, maka penelitian ini dilanjutkan pada pengujian hipotesis. Hasil analisis Uji-t data kompetensi pengetahuan PKn disajikan pada Tabel 4 berikut ini.

Tabel 4. Hasil Uji-t Data Kompetensi Pengetahuan PKn

\begin{tabular}{llcrrrrr}
\hline No. & \multicolumn{1}{c}{ Sampel } & $\mathrm{N}$ & $\mathrm{Dk}$ & $\bar{X}$ & $\mathrm{~S}^{2}$ & $\mathrm{t}_{\text {hitung }}$ & $\mathrm{t}_{\text {tabel }}$ \\
\hline 1 & Kelompok Eksperimen & 34 & \multirow{2}{*}{65} & 66,79 & 124,67 & \multirow{2}{*}{2,30} & \multirow{2}{*}{2,000} \\
2 & Kelompok Kontrol & 33 & & 60,64 & 113,13 & \\
\hline
\end{tabular}

Berdasarkan tabel 4 tersebut, dijelaskan hasil dari pengujian hipotesis diperoleh $t_{\text {hitung }}=2,30$. Harga tersebut kemudian dibandingkan dengan harga $t_{\text {tabel }}$ dengan $d k=34+33-2=65$ dan taraf signifikansi $5 \%$ sehingga diperoleh harga $t_{\text {tabel }}=2,000$, karena $t_{\text {hitung }}>t_{\text {tabel }} t_{\text {hitung }}=2,30>t_{\text {tabel }}(\alpha=0,05)=2,000$ maka Ho ditolak atau Ha diterima. Hal ini berarti terdapat perbedaan yang signifikan kompetensi 
pengetahuan PKN antara kelompok siswa yang dibelajarkan melalui pembelajaran quantum berbasis kearifan lokal tat twam asi dengan kelompok siswa yang dibelajarkan melalui pembelajaran konvensional pada kelas IV SD Gugus PB. Sudirman Denpasar Barat Tahun Ajaran 2016/2017.Rerata kompetensi pengetahuan PKN siswa kelompok eskperimen 66,79 lebih besar dari 60,64 yiatu rerata kompetensi pengetahuan PKN siswa kelompok kontrol. Sehingga dapat disimpulkan bahwa penerapan pembelajaran Quantm berbasis kearifan lokal Tat Twam Asiberpengaruh terhadap kompetensi pengetahuan PKN siswa kelas IV SD Gugus PB. Sudirman Denpasar Barat Tahun Ajaran 2016/2017.

Rerata kompetensi pengetahuan PKn siswa kelompok eskperimen $=66,79>=60,64$ rerata kompetensi pengetahuan PKn siswa kelompok kontrol. Sehingga dapat disimpulkan bahwa penerapan pembelajaran quantum berbasis kearifan lokal tat twam asiberpengaruh terhadap kompetensi pengetahuan PKN siswa kelas IV SD Gugus PB. Sudirman Denpasar Barat tahun ajaran 2016/2017.

Perolehan data kompetensi pengetahuan PKN pada kedua kelompok dapat diketahui bahwa kedua kelompok yang awalnya memiliki kemampuan setara, lalu setelah diberikan perlakuan yang berbeda, perolehan data kompetensi pengetahuan PKN mengalami perbedaan. Kompetensi pengetahuan PKN siswa pada kelompok eksperimen lebih baik apabila dibandingkan dengan kompetensi pengetahuan PKN siswa pada kelompok kontrol. Hal ini disebabkan oleh pembelajaran yang diterapkan pada kelompok eksperimen memiliki keunggulan.

Pembelajaran Quantum dipadukan dengan kearifan lokal Tat Twam Asi membuat siswa lebih disiplin dalam proses pembelajaran dan pembelajaran menjadi lebih bermakna. Hal itu karena pembelajaran quantum dipadukan dengan kearifan lokal tat twam asi menekankan kepada siswa untuk membangun pengetahuannya sendiri dengan menekakankan toleransi dalam pelaksanaan pembelajaran, contoh-contoh yang diberikan dalam pembelajaran dapat dialami langsung oleh siswa itu sendiri. Hal ini sejalan dengan Koolang, Rede \& Jamhari (2013) meningkatnya hasil belajar IPA pada materi berbagai peristiwa alam di kelas V SDN Pakanangi melalui model pembelajaran quantum teaching. Siswa yang mengikuti pembelajaran quantum (Quantum Teaching) terbukti telah mampu meningkatkan prestasi belajar IPA mereka dari kategori cukup sebelum mereka dilibatkan dalam pembelajaran quantum menjadi kategori tinggi setelah mereka mengikuti pembelajaran dengan model quantum (Susiani dkk, 2013). Partiwi (2013) menyatakan bahwa pembelajaran quantum berbasis kontekstual tepat digunakan dalam pembelajaran di SD karena dalam penerapanya lebih banyak mengaitkan materi pembelajaran dengan konteks budaya dan lingkungan siswa. Sehingga dengan mengaitkan materi dengan kehidupan seharihari, siswa lebih mudah membangun pengetahuannya sendiri dan pembelajaran menjadi lebih bermakna.

Pembelajaran quantum berbasis kearifan lokal tat twam asi memberikan pengalaman belajar bagi siswa dimana pendekatan pembelajaran ini akan menumbuhkembangkan kemampuan siswa untuk memecahkan masalah secara inovatif yang dilandaskan pada ajaran susila atau etika sehingga siswa dapat saling menghargai antar sesama dan menekan ego yang menjadi penghalang untuk menyadari bahwa pada dasarnya diri kita semua adalah sama. Berbeda dengan pendekatan saintifik yang terjadi selama pembelajaran PKn di kelompok kontrol. Kegiatan pembelajaran dilakukan dengan menerapkan pembelajaran yang sudah biasa dilakukan dan berpatokan pada buku pegangan sehingga pembelajaran menjadi monoton.

Hasil penelitian ini menguatkan beberapa hasil penelitian yang ditemukan belakangan ini, yakni penelitian yang dilakukan oleh peneliti: Kd. Dwi Suarnaya (2015) dengan judul penelitian pengaruh model pembelajaran TANDUR berbasis kearifan lokal tri kaya parisudha terhadap hasil belajar IPA. Penelitian yang dilakukan oleh peneliti: I Kadek Suartana (2014) dengan judul penelitian pengaruh model pembelajaran kuantum dengan teknik peta konsep terhadap hasil belajar PKn. Begitu juga dengan hasil penelitian Setiawati (2017) yang menemukan bahwa pembelajaran tematik dengan Quantum Teaching di kelas III pembelajaran akan bermakna dan kegiatan belajar lebih dinamis, menginspiratif, dan menyenangkan.

\section{SIMPULAN DAN SARAN}

Terdapat perbedaan yang signifikan kompetensi pengetahuan PKN antara kelompok siswa yang dibelajarkan melalui pembelajaran quantum berbasis kearifan lokal tat twam asi dengan kelompok siswa yang dibelajarkan melalui pembelajaran konvensional pada kelas IV SD Gugus PB.Sudirman Denpasar Barat dengan derajat kebebasan 5\%. Itu tersbukti dari hasil analisis uji t diperoleh $t_{\text {hitung }}=2,30$. Harga tersebut kemudian dibandingkan dengan harga $t_{\text {tabel }}$ dengan $d \mathrm{k}=34+33-2=65$ dan taraf signifikansi $5 \%$ sehingga diperoleh harga $t_{\text {tabel }}=2,000$, karena $t_{\text {hitung }}>t_{\text {tabel }} t_{\text {hitung }}=2,30>t_{\text {tabel }}(\alpha=0,05)=2,000$ maka Ho ditolak atau Ha diterima. Hal ini berarti terdapat perbedaan yang signifikan kompetensi pengetahuan PKN antara kelompok siswa yang dibelajarkan melalui pembelajaran quantum berbasis kearifan lokal tat twam asi dengan kelompok siswa yang dibelajarkan melalui pembelajaran konvensional pada kelas IV SD Gugus 
PB. Sudirman Denpasar Barat.Rerata kompetensi pengetahuan PKN siswa kelompok eskperimen $=66,79$ $>=60,64$ rerata kompetensi pengetahuan PKN siswa kelompok kontrol. Sehingga dapat disimpulkan bahwa penerapan pembelajaran quantum berbasis kearifan lokal tat twam asi berpengaruh terhadap kompetensi pengetahuan PKN siswa kelas IV SD Gugus PB. Sudirman Denpasar Barat tahun ajaran $2016 / 2017$.

Keberhasilan dalam muatan pembelajaran PKN dengan menerapkan pembelajaran quantum berbasis kearifan lokal tat twam asimerupakan salah satu cara untuk melaksanakan pembelajaran guna mencapai hasil belajar yang optimal. Berdasarkan hasil penelitian ini, maka saran yang dapat diajukan adalah sebagai berikut. 1) Bagi Guru, melihat hasil penelitian pada muatan pembelajaran PKN dengan penerapan pembelajaran berbasis kearifan lokal tat twam asi ini, hendaknya guru menerapkan pembelajaran quantum berbasis kearifan lokal tat twam asipada muatan pembelajaran PKN di waktuwaktu tertentu. 2) Bagi Sekolah, sekolah hendaknya menyediakan sarana yang maksimal untuk menunjang pembelajaran agar siswa semakin termotivasi untuk belajar dan memanfaatkan sarana tersebut untuk mengoptimalkan hasil belajar siswa sehingga mutu sekolah menjadi semakin meningkat. 3) Bagi Peneliti Lain, dengan dilakukannya penelitian ini, diharapkan peneliti lain melakukan penelitian lebih lanjut dengan menerapkan pembelajaran quantum berbasis kearifan lokal tat twam asi. Pada materi pembelajaran yang berbeda atau dapat pula dilakukan penelitian lebih lanjut dengan menggunakan pembelajaran quantum berbasis kearifan lokal tat twam asi pada sumber data/sampel yang berbeda khususnya pada muatan pembelajaran PKN sehingga hasil penelitian benar-benar dapat menggambarkan keadaan sesungguhnya yang terjadi di lapangan.

\section{DAFTAR RUJUKAN}

Afa, Yulita Faizul, I.Gst. A. Oka Negara \& I Kt. Adnyana Putra. 2014. Pengaruh Strategi Pembelajaran Quantum Teaching Dengan Dukungan Media Audio - Visual Terhadap Hasil Belajar IPA Siswa. Jurnal Mimbar PGSD Universitas Pendidikan Ganesha. Volume 2, Nomor 1

Aka, Kukuh Andri. 2016. Model Quantum Teaching Dengan Pendekatan Cooperative Learning Untuk Meningkatkan Kualitas Pembelajaran PKn. Jurnal Pedagogia. Volume 5, Nomor 1 (hlm. 35-46)

Astuti, Ni Md. Rai, I Kt. Ardana \& I. B. Surya Manuaba. (2013). Pengaruh Model Quantum Learning Berbantuan Media Lingkungan Terhadap Hasil Belajar IPA Siswa Kelas IV SD Gugus III Kerobokan Badung. Jurnal MIMBAR PGSD Universitas Pendidikan Ganesha. Volume 1 Nomor 1

Buacani. 2016. Upaya Meningkatkan Motivasi Belajar dan Kemampuan Menghitung Luas Bangun Datar dan Segi Banyak Melalui Pendekatan Quantum Learning di Kelas VI SDN Inpres 5 Birobuli. Jurnal Kreatif Tadulako Online. Vol. 4 No10 (hlm. 250-261)

Dantes, Nyoman. 2012. Metode Penelitian. Yogyakarta: Andi

Daryanto. 2014. Pendekatan Pembelajaran Saintifik Kurikulum 2013. Yogyakarta: Gava Medika

DePorter, Bobbi dkk. 2014. Quantum Teaching. Bandung: Kaifa

Koolang, Salim Mulyadi, Amran Rede \& Mohammad Jamhari. 2013. Meningkatkan Hasil Belajar Siswa pada Materi Berbagai Peristiwa Alam di Kelas V SDN Pakanangi melalui Model Pembelajaran Quantum Teaching. Jurnal Kreatif Tadulako Online. Vol. 1 No. 2 (hlm. 1-8)

Kunandar. 2013. Penilaian Autentik (Penilaian Hasil Belajar Peserta Didik Berdasarkan Kurikulum 2013). Jakarta: Rajawali Pers

Kurniawati, Narulita Setyaningrum \& Moch.Syaichudin.2014. Implementasi Model Pembelajaran Quantum Learning Untuk Mata Pelajaran Bahasa Indonesia Kompetensi Dasar Menulis Karangan Kelas V SDN Lidah Wetan IV Surabaya. Volume 2 Nomor 1

Kusumawardani, Irlaila. 2016. Penerapan Quantum Learning Untuk Meningkatkan Motivasi Belajar Siswa Pelajaran PKn Kelas VA SDN Pungkuran. Jurnal Pendidikan Guru Sekolah Dasar Edisi 20 (hlm. 19231933

Partiwi, Dw. A. Pt. Oka, Nym. Dantes \& I Dw. Pt. Raka Rasana. 2013. Pengaruh Model Pembelajaran Quantum Berbasis Kontekstual Terhadap Hasil Belajar Ipa Siswa Kelas IV SD di Gugus II Kecamatan Buleleng. Jurnal Mimbar PGSD Universitas Pendidikan Ganesha. Volume 1, Nomor 1

Peraturan Menteri Pendidikan dan Kebudayaan Nomor 57 Tahun 2014 
Setiawati, Nani , H. Marzuki \& Hj. Sri Utami. 2017. Implementasi Pembelajaran Tematik Dengan Quantum Teaching di Kelas III Sekolah Dasar Negeri 21. Jurnal Pendidikan dan Pembelajaran. Volume 6, Nomor 3

Suarnaya, Kd. Dwi. 2015. "Pengaruh Model Pembelajaran TANDUR Berbasis Kearifan Lokal Tri Kaya Parisudha Terhadap Hasil Belajar IPA".e-journal PGSD UNDIKSHA Jurusan PGSD Volume 3 Nomor 1

Suartana. 2014. "Pengaruh Model Pembelajaran Kuantum dengan Teknik Peta Konsep terhadap Hasil Belajar PKn". e-journal PGSD UNDIKSHA Jurusan PGSD Volume 2 Nomor 1

Subagiasta, I Ketut. 2007. Etika Pendidikan Agama Hindu. Surabaya: Paramita.

Sugiyono. 2012. Metode Penelitian Kuantitatif Kualitatif dan R\&D. Bandung: Alfabeta

Sukarsa, I Wy., Ny. Dantes \& Ni Wy. Arini. 2014. Penerapan Model Pembelajaran Kuantum Berbantuan Media Microsoft Powerpoint Untuk Meningkatkan Aktivitas dan Hasil Belajar IPA Siswa Kelas IV Semester 1 SD Negeri 6 Menanga. Jurnal Mimbar PGSD Universitas Pendidikan Ganesha. Volume 2, Nomor 1

Susanto, Ahmad. 2015. Teori Belajar dan Pembelajaran di Sekolah Dasar. Jakarta: Prenamedia Group

Susiani, Ketut, Nyoman Dantes \& I Nyoman Tika. 2013. Pengaruh Model Pembelajaran Quantum Terhadap Kecerdasan Sosio-Emosional dan Prestasi Belajar IPA Siswa Kelas V SD di Banyuning. e-Journal Program Pascasarjana Universitas Pendidikan Ganesha. Volume 3

Trisnawati, Dhoriva Urwatul Wutsqa. 2015. Perbandingan Keefektifan Quantum Teaching Dan Tgt Pada Pembelajaran Matematika Ditinjau Dari Prestasi Dan Motivasi. Jurnal Riset Pendidikan Matematika. Volume 2, Nomor 2 (hlm. 297 - 307)

Undang-undang Nomor 39 Tahun 1999

Undang-undang Republik Indonesia Nomor 20 Tahun 2003 tentang Sistem Pendidikan Nasional 